\title{
Development of e-learning for English class
}

\author{
Noni Agustina, ${ }^{1, *}$, and Nugroho Budhisantosa ${ }^{2}$ \\ ${ }^{1}$ Primary Teacher Education Department, Education and Teacher Training Faculty, Esa Unggul \\ University, 11510, Arjuna Utara Street, Jakarta, Indonesia \\ ${ }^{2}$ Information Systems Department, Computer Science Faculty, Esa Unggul University, 11510, Arjuna \\ Utara Street, Jakarta, Indonesia
}

\begin{abstract}
In the twenty first century, teachers are required to have a digital literacy skill. They must be able to integrate technology in learning process. It was already conducted by a teacher in one of public junior high schools in Jakarta. She searched the materials from the internet but she had a problem to adjust the learning materials to her students' needs and characteristics. Therefore, this study was undertaken to explore deeply how to develop e-learning in English class based on her students' needs and characteristics. This study employed research and development methodology. The participants were an English teacher and the first graders of junior high school. The result showed that this e-learning used PHP, Framework Bookstrap and MySQL. The e-learning also used Adobe Flash and Adobe Illustrator to make some animated videos. It consisted of listening, reading, and grammar which the topic focused on descriptive texts comprising some themes referring to 2013 curriculum. Those themes were people, animal, thing, place, and occupation. The development of e-learning deserved to be implemented after it was validated by the expert, evaluated by the teacher and tested to the students. It is expected to contribute as supplemental learning media in English learning process.
\end{abstract}

Keywords: English skill, e-learning, research and development

\section{Introduction}

The proliferation of information communication and technology grows rapidly nowadays. That phenomenon can be seen from the high use of cell phone and the internet around the world. 3.15 billion people use the cell phone and 3 billion people use the internet $[1,2]$. Internet is highly demand in our life [3]. The use of the internet in Indonesia increases 100 percent each year [4]. It offers all information needed around the world [5]. It affects the education world [3]. It influences the teaching and learning process in the class $[6,7,8]$. When the previous observation was conducted, one of teachers at public junior high school in West Jakarta, Indonesia used the laptop and projector as well the speaker

* Corresponding author: noni@esaunggul.ac.id 
when teaching English in the class. She taught her students using video downloaded from the internet. Sometimes, she used the online learning such as Edmodo to teach her students. She was a portray of a teacher in the twenty first century that she had the digital literacy. The teacher needs the ability to use the information and communication technology in their classroom such as the internet use [9]. The Ministry of Education and Culture of Republic of Indonesia also determine the national literacy movements. One of them is the digital literacy. It means that Indonesian government has been supporting schools to implement the digital literacy. Nowadays, they applied computer-assisted test for the national test in some schools for some areas around Indonesia.

Based on the previous interview, even though the teacher integrated the technology in teaching English in the classroom, she had problem to adjust the material she found from the internet to meet her students' needs and characteristics. She also had difficulty to find resources such as listening. Although, information and technology centre of the Ministry of Education and Culture provides the e-learning in website (http://edukasi.kemdikbud.go.id/), it cannot be accessed because it always comes up "file or directory not found' command. The e-learning also has not been much more developed in Indonesia $[10,11]$. To address those problems, this study is important to undertaken by developing English e-learning. There are some various terminologies used addressing the e-learning: web-based learning, online learning, computer-based learning or computerbased instruction. Morrison and Aparicio et al. call it online learning [12, 13]. Even though it has different names, it is used in teaching and learning process involving the technology such as computer network (internet/ intranet) or multimedia [13, 14, 15]. It has some functions: supplementary and substitution functions. Supplementary function means that it can be combined with the conventional learning which emphasizes on face-to-face learning in the classroom. It is used to enrich the learning process. On the other hand, substitution function means using e-learning fully in learning process [11]. A study showed that the e-learning and traditional education are still used together. They complete each other in order to reach the educational result [16].

Some studies found that the e-learning was more effective than traditional instruction [17]. It has some advantages [14]. It can support the learning process [3, 18, 19, 20]. It gains the academic achievement, motivation, performance and attitudes $[14,15,17]$. It facilitates the teachers to provide learning materials and they ask their students to accomplish and submit the assignments or exercises. The learning process is also fun, interactive and effective by using it [19]. It provides the flexibility of time, place, learning speed, instructional standardization and effective instructional. The slow students can learn the material or tutorial provided in the e-learning. It can help them [4]. The students also can learn autonomously [14].

The previous studies were undertaken by some researchers in developing the elearning. Yaniawati and Muis et al. conducted the e-learning for mathematic class. Munir dan Prabowo developed the e-learning using SMS Joomla for vocational high school students in Bantul, Indonesia which its content was about computer sciences. Turino et al. developed e-learning for teaching listening skill for senior high school (SMA 4) in Semarang, Indonesia. He designed it using Adobe Flash Professional CS3 in swf format. Setyowati focused on reading skill for senior high school students, thus she designed the e-learning for reading. Sutisna developed the e-learning for teaching grammar class at English Class Department, Pakuan University, Indonesia. The result showed that students' understanding on grammar and their motivation increased when they used e-learning and they could access it easily. It's a useful tool for the lecturer too when teaching grammar [21]. Siswono and Liona also developed e-learning which emphasized on phonology, syntax, semantic, and pragmatic. They provided stories with proper grammar and the result showed that the teacher was easier to teach grammar to the students and it helped 
students to understand the grammar well. Solak \& Cakir developed the course of elearning consisted of basic English skills which contain animation and interactive presentation for higher education level. The students also were able to discuss with their teachers in a synchronized way. Rymanova et al. developed e-course using Moodle as the Learning Management System which its contents were lexical, grammar, and speaking skill. From the studies, it could be concluded that the e-learning for English class concerning on some English skills. It is developed for senior high school level and mostly for higher education level [22]. In USA, almost 90 percent of universities use it [4] and in Korea 70 percent [23]. Thus, this study develops listening, reading, and grammar for English learning at junior high school level especially for first grade. The study aims to explore and describe deeply the development of the English the e-learning by applying a need analysis. It is required to design the instructional material for the e-learning [24].

\section{Method}

This study employed research and development methodology. Its aim was to yield a product [25]. It had many kinds of model used. Those models had different steps and processes [6]. This study applied model developed by Gall, Gall and Borg but did not fully complete all processes due to the time constraint. The process consisted of conducting need assessment, planning (identifying skills that will be learnt, generating the objective and learning activities, and having expert's validation), revising the products referring to the feedback given by the experts, conducting the field testing of the product to three students and teacher, and revising the product based on students and teachers' feedback.

This study was conducted from January to June 2017. The participants of this study were first graders and an English teacher of 89 Junior High School in West Jakarta, Indonesia. Interviewing the teacher was undertaken to obtain the data what she and her students needed. The document analysis (the syllabi) was also required to write the objective so it could be used a supporting data. The instruments used to validate media and content of e-learning were given to the experts. The questionnaire for teacher and students are also provided to get their feedback.

\section{Result and Discussion}

Based on the need analysis, students required to learn listening and reading skills which focused on descriptive texts. Those descriptive texts had some themes such as people, animal, place, thing, and occupation. The materials referred to the 2013 curriculum. Not only listening and reading skills, they were also necessary to learn grammar such as simple present tense, adjective, adverb, and preposition. After analysing the needs, the next steps were making the e-learning content, determining the name of e-learning website, making the logo, making the login for the students and teacher (administrator), developing English Gate by using PHP, Framework Bootstrap, and MySQL, making Entity Relationship Diagram (ERD), inputting the content into database system, hosting all database systems created in mini Raspberry Pi 3, sending English Gate as English e-learning to be validated, and testing English Gate to three students.

The content of e-learning consisted of listening, reading, and grammar. The listening contained the audio by recording an American native speaker's voice. It provided the audio with the animation, vocabulary (English-Indonesia), and multiple-choice questions. When students clicked the words in vocabulary, they had sound. The reading provided some texts with the sound, pictures, vocabulary, and short-answer questions. The students had to type the answer in the box provided. The grammar had the animated video which aimed to help 
the students to learn adjective, adverb, preposition and simple present tense. After they watched the animated video, they could play the game by accomplishing some exercises related to the grammar they learnt before. The exercises were in fill-in-the blank format. The students also could see their result and the answer key after they finished answering the exercises. The animations were created by using some software such as Adobe Flash and Adobe Illustrator.

English Gate was chosen as the name of the English e-learning. The logo was created using Adobe Illustrator. It provided login for the students and teacher (administrator). Students' login could be used to learn the material, do the exercises and see their scores. Administrator's login could be used to see the students' score, assess her/his students' score, register students' data, edit and delete the questions and answers. It used PHP as a back-end, Framework Bootstrap as front-end and MySQL as a database system. Entity Relationship Diagram (ERD) was used to describe the logical structure of database.

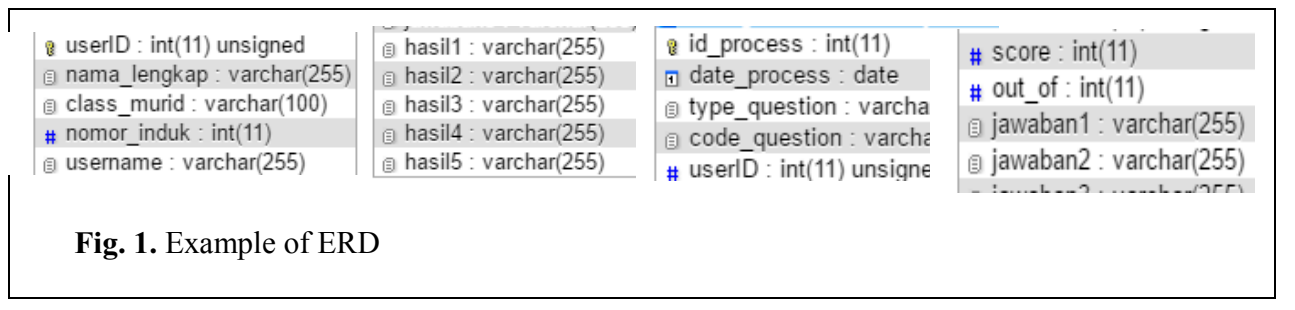

The contents were inputted into the database system. They were the homepage of English Gate consisting of home, login, about us, listening, reading, and grammar; username and password of administrator for login in the administrator dashboard; the questions by clicking 'manage question' in the administrator dashboard. All those data base systems created were hosted in mini Raspberry Pi 3 that functioned as web server. Thus, the IP address of the web server was 192.168.1.200.

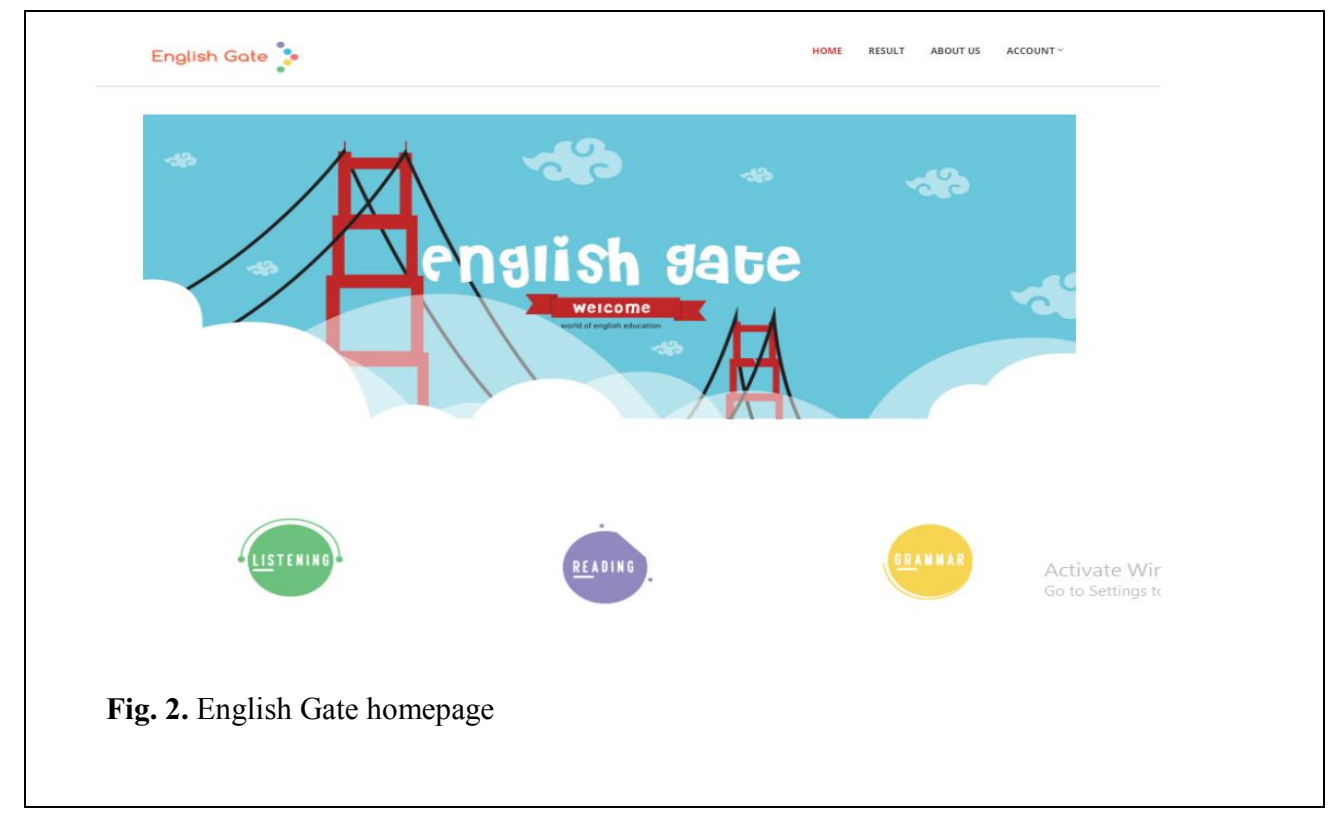




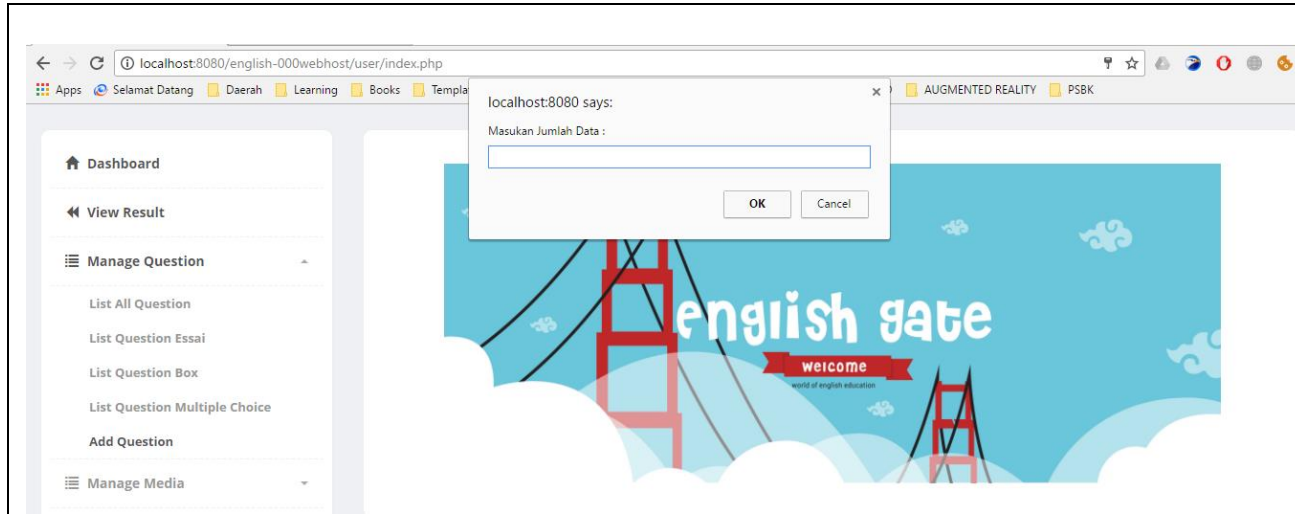

Fig. 3. Administrator dashboard

English Gate was sent to two experts and teacher to validate its media and content. The result showed that the content was good and the content expert and the teacher did not give any suggestion about the content. On the other hand, the media experts gave some feedback. The feedback was the homepage display should be added and provided the manual how to use English Gate. Referring to those suggestion, it was revised and sent back to be validated again. The second validation showed the e-learning deserved to be applied and tested to some students.

These results of this study were not fully similar to the previous study. The development of the e-learning (English gate) consisted of login, homepage, interactive learning material (listening, reading and grammar) consisting of animated video, and quizzes with the feedback. The previous study found that the components of the e-learning contents were varied. This result study showed that Morrison developed it consisting of register, login, personal profile, material consisting of pre-assessments, texts, pictures, simulations, interactive exercises, downloaded materials, quizzes, bookmarks, post-assessments, and feedback[19]. It's a little bit different from Morrison, Munir and Prabowo developed their e-learning content comprising curriculum, syllabus, materials and tests. Turino, et al. also provided login, homepage, syllabi, evaluation, and online consultation and chatting forum. Login was for the administrator, students, and teachers. The homepage consisted of main menu, register, and learning menu which offered downloaded material for students and teachers. The materials were in audio, Microsoft Word, Microsoft PowerPoint, PDF, and animation format. The listening materials developed used Adobe Flash Professional CS3. The syllabi were also provided, if the teachers wanted to delete or add them, they could do it. The evaluation comprised the questions and answers with various format such as multiple choice and true-false. The online consultation and chatting forum were designed to facilitate the students' interaction and participation. Almost similar to the previous researchers, Siswono dan Liona developed their e-learning consisting of login, learning plan, lesson, story, exercise, and dictionary. The learning plan provided a year learning planning. The lessons were the materials given to the students. The story feature consisted of animations with different themes. The dictionary was useful for the students to find the meaning of words [27]. Rymanova et al. developed the e-learning, namely e-course, which consisted of the general data (teachers' personal data), unit feature (instructional unit, materials such as vocabulary and grammar, glossary, activities and supplementary resources from internet, and assessment feature. The materials were video, animation, text or images. They also provided Forum, Chat, and Wiki which facilitated students to interact 
with their instructors or teachers. The tests of units had some variations such as multiple choice, matching, short answer and other forms [14].

English Gate was tested to three students. They were observed by recording them when they used it. The result showed that they could use it well. Then they were given a questionnaire sheet to know their response in using it. All of them urged that they were happy to use it and more understand to learn English. The vocabulary also helped them to understand the meaning of words. Some of them gave suggestion to improve the assessment of reading because they thought their answers were correct but they had unsatisfying scores. Therefore, the teacher had to rechecked their reading answers and scores. Some studies showed that the content of the e-learning was not absolutely same one another. The important thing was it gave a significant impact for the students. It could be accessed autonomously by the students, flexible use, effective and efficient. Siragusa (2000) revealed that the main components in online learning were content, interaction, feedback, and interface design. The content had to align to the purpose and students' ability. The interaction referred to the communication between the students and teachers or instructors. The feedback referred to the teachers' comment or suggestions given to the students both individually or in group. The interface referred to easy navigation that could help and respond the students. The use of image, colour, sound, animation could entice the students [17]

\section{Conclusion}

English Gate is a web-based learning that can be used to learn English especially listening, reading, and grammar which it is developed for first graders of junior high school. Its contents are login, homepage, interactive learning material (listening, reading and grammar) consisting of animated video, and quizzes with the feedback. It is also equipped with the vocabulary (English-Indonesia) as aid tool for the students. It is expected to give a contribution as a learning source for students to enhance their English ability. This study needs some further improvement in reading assessment because students' possibility answers are varied. Further research is also required to investigate the effectiveness of English Gate as e-learning if it is applied in some classes.

This study is supported by grant of Ministry of Research, Technology and Higher Education of the Republic of Indonesia.

\section{References}

1. A. Koller, G. Foster, M.Wright, ACM International Conference Proceeding Series, 131-138 (2008)

2. M. Kende, Internet Society, 146 (2014). http://www.internetsociety.org

3. E. Solak \& R.Cakir, E-Learning Digital Media, 12, 107-120 (2015)

4. E. Effendi and H. Zhuang, E-learning Konsep dan Aplikasi, 4 (2005)

5. D.H. Eldardiry and Z.A. Elmoghazy, Int J Technol Des Educ, 1-16 (2016)

6. H. Cai, Procedia IERI, 841-846 (2012)

7. J. Loizzo and P.A. Ertmer, Education Tech Research Dev, 1-20 (2016)

8. N.Tuncay \& Uzunboylu, Procedia - Soc. Behav. Sci, 47, 131-137 (2012)

9. H. L. Chou, \& C. H. Chen, Comput. Educ, 103, 124-133 (2016)

10. Setyowati, Lib UI, 1-8 (2009). http://lib.ui.ac.id/

11. Turino et al., Jurnal Teknologi Informasi, 5, 725-728 (2009) 
12. D. Morrison, E-learning strategies. How to get implementation and delivery right first time, 10-11(2003)

13. M. Aparicio et al., Journal of Educational Technology \& Society, 19, 292-307 (2016)

14. I. Rymanova, N. Baryshnikov \& A.Grishaeva, Procedia - Soc. Behav. Sci, 206, 236$240(2015)$

15. N. Mohammadi, V. Ghorbani \& F. Hamidi, Procedia Comput. Sci., 3, 464-468 (2011)

16. C. J. Kim \& R. Santiago, Educ. Technol. Res. Dev, 53, 108-115 (2005)

17. R. Khodabandelou, \& S. A. A Samah, Procedia - Soc. Behav. Sci., 67, 545-552 (2012)

18. M.B. Triyono, Procedia Social and Behavioral Science, 55-61 (2014)

19. Muis et al., Pelaksanaan Pembelajaran Berbasis E-Learning Bidang Studi Matematika Pada SMP Negeri 1 Magelang, 1-17(2012). http://eprints.ums.ac.id/

20. M. Munir and K. Prabowo, Pengembang E-Learning Berbasis Multimedia Sebagai Multimedia Center Untuk Meningkatkan Kualitas Pembelajaran TKJ di SMK, 1-9 (2011). http://staff.uny.ac.id/

21. E. Sutisna, Model Pembelajaran Grammar Berbasis Website, 10, (2013). http://digilib.upi.edu/

22. L. Xiangqian, \& G. Fuqing, IERI Procedia 2, 854-858 (2012)

23. D.Josic et al., Educ. Technol. Res. Dev, 59, 445-464 (2011)

24. H. Hussin, F. Bunyarit, R.Hussein, Campus-Wide Inf. Syst. 26, 4-19 (2009)

25. Sugiyono, Metode penelitian kuantitatif kualitatif dan $R \& D, 297$ (2012)

26. N. Putra, Reseach and Development. Penelitian dan Pengembangan: Suatu Pengantar, 119-121(2015)

27. Siswono and Y. Liona. Jurnal ComTech, 1, 300-308 (2010) 